\title{
Helicobacter pylori transiently in the mouth may participate in the transmission of infection
}

\author{
Denise G Silva $^{1,2}$, Eduardo MB Tinoco ${ }^{1,2}$, Gifone A Rocha ${ }^{3}$, Andreia Maria Camargos Rocha ${ }^{3}$, \\ Juliana B Guerra3 ${ }^{3}$ Ivan EB Saraiva ${ }^{3}$, Dulciene MM Queiroz ${ }^{3 /+}$
}

\begin{abstract}
'Escola de Odontologia, Universidade do Grande Rio, Duque de Caxias, RJ, Brasil ²Departamento de Procedimentos Clínicos Integrados, Faculdade de Odontologia, Universidade do Estado do Rio de Janeiro, Rio de Janeiro, RJ, Brasil ${ }^{3}$ Laboratório de Pesquisa em Bacteriologia, Faculdade de Medicina, Universidade Federal de Minas Gerais, Av. Prof. Alfredo Balena 190/216, 30130-100 Belo Horizonte, MG, Brasil
\end{abstract}

Helicobacter pylori infection is associated with peptic ulcer and gastric carcinoma. The oral cavity may be a reservoir for $\mathrm{H}$. pylori; however, the results of studies on this subject are controversial. We employed single-step and nested polymerase chain reactions (PCR) to detect the presence of the $\operatorname{vac} A$, ure $A$ and $16 S$ rDNA genes of $\mathrm{H}$. pylori in the stomach, saliva and dental plaque of 30 subjects. The results were confirmed by sequencing. Nested $16 \mathrm{~S}$ rDNA and ure $A$ amplification was achieved in $80 \%$ of gastric, $30 \%$ of saliva and $20 \%$ of dental plaque specimens. Sequencing of 10, seven and four $16 S$ rDNA products from stomach, saliva and dental plaque, respectively, showed $>99 \%$ identity with $\mathrm{H}$. pylori. Sequencing of the other four oral cavity PCR products showed similarity with Campylobacter and Wolinella species. Additionally, the vacA genotype identified in the samples of different sites was the same within a given subject. H. pylori may be found in the oral cavity of patients with gastric infection, thus it could be a source of transmission. However, results obtained with detection methods based only on PCR should be interpreted with caution because other microorganisms that are phylogenetically very close to $\mathrm{H}$. pylori are also present in the mouth.

Key words: H. pylori - dental plaque - saliva - oral cavity - transmission - vacA

Helicobacter pylori infection, one of the most common chronic bacterial infections worldwide, is considered to play an important role in the pathogenesis of peptic ulcer disease (Mégraud \& Lamouliatte 1992), distal gastric carcinoma (Parsonnet et al. 1991) and gastric mucosa-associated lymphoid tissue lymphoma (Wotherspoon et al. 1991). Recently, questions have been raised concerning the possibility that the oral cavity is an $H$. pylori reservoir participating in infection transmission or a nidus for reinfection after eradication therapy or that it plays a role in oral disease. However, the results of the studies on this subject are controversial. Different groups have found discrepant results, ranging from $0-100 \%$ positivity for $H$. pylori in the oral cavity by polymerase chain reaction (PCR) methods (Mapstone et al. 1993, Hardo et al. 1995, Parsonnet et al. 1999, Song et al. 2000, Fritscher et al. 2004, Loster et al. 2006, Olivier et al. 2006). In addition, inconsistent correlation between $H$. pylori positivity in the oral mucosa and in the stomach has been found. Many factors likely account for this variability, including the genetic background of the study population, cultural habits, socioeconomic level and differences in the accuracy of the methods used as well as the strain of bacteria.

Financial support: CNPq, FAPEMIG

+Corresponding author: dqueiroz@medicina.ufmg.br

Received 23 October 2009

Accepted 27 April 2010
Our goal was to investigate the presence of $H$. pylori in the stomach and oral cavity. We employed highly sensitive PCR assays followed by sequencing to increase the specificity of the PCR results.

\section{PATIENTS, MATERIALS AND METHODS}

We included 30 patients (17 males and 13 females; mean age $=53.4$ years, standard deviation $=4.3$ years) who were consecutively selected among those who underwent upper endoscopy at the Endoscopy Service of the Pedro Ernesto Hospital of Rio de Janeiro State University in Rio de Janeiro, Brazil to clarify the origin of their dyspeptic symptoms. The patients had received neither proton pump inhibitors nor antimicrobials in the two months prior to endoscopy. Those who had less than 20 teeth in their mouth were excluded from the study. The study was approved by the Ethical Committee of the institution and informed consent was obtained from all included patients. Antral biopsy specimens obtained during the endoscopy were kept at $-80^{\circ} \mathrm{C}$ until DNA was extracted. Saliva and dental plaque samples were collected from each patient immediately before endoscopy using sterile paper points that were placed into $1.5 \mathrm{~mL}$ microtubes containing $1.0 \mathrm{~mL}$ of sterile water. Approximately $1.0 \mathrm{~mL}$ of non-stimulated salivary flow was also collected in a $1.5 \mathrm{~mL}$ microtube. For plaque sampling, air drying and sterile cotton rolls were used to avoid saliva contamination. Samples were kept in dry ice, transported to the laboratory and then stored at $-80^{\circ} \mathrm{C}$ before DNA was extracted.

DNA was extracted with the QIAamp DNA Mini kit (Qiagen GmbH, Hilden, Germany) according to the manufacturer's recommendations, with minor modifi- 
TABLE I

Oligonucleotide primers used for polymerase chain reaction (PCR) amplification of 16S rRNA and ureA genes

\begin{tabular}{|c|c|c|}
\hline Primers and sequence $\left(5^{\prime}-3^{\prime}\right)$ & $\begin{array}{l}\text { Amplicon size } \\
\text { (bp) }\end{array}$ & PCR conditions \\
\hline \multicolumn{3}{|l|}{ 16S rRNA } \\
\hline \multicolumn{3}{|l|}{ Outer primers } \\
\hline C70: AGAGTTTGATYMTGGC & 1,500 & $\begin{array}{c}94^{\circ} \mathrm{C}(45 \mathrm{~s}), 50^{\circ} \mathrm{C}(45 \mathrm{~s}), 72^{\circ} \mathrm{C}(45 \mathrm{~s}), \\
5 \mathrm{~s} \text { per cycle }-24 \text { cycles }\end{array}$ \\
\hline \multicolumn{3}{|l|}{ B37: TACGGYTACCTTGTTACGA } \\
\hline \multicolumn{3}{|l|}{ Inner primers } \\
\hline C97: GCTATGACGGGTATCC & 400 & $\begin{array}{l}94^{\circ} \mathrm{C}(1 \mathrm{~min}), 55^{\circ} \mathrm{C}(2 \mathrm{~min}) \\
72^{\circ} \mathrm{C}(3 \mathrm{~min})-34 \text { cycles }\end{array}$ \\
\hline \multicolumn{3}{|l|}{ C98: GATTTTACCCCTACACCA } \\
\hline \multicolumn{3}{|l|}{ UreA } \\
\hline \multicolumn{3}{|l|}{ Outer primers } \\
\hline HPU1: GCCAATGGTAAATTAGTT & 411 & $\begin{array}{l}94^{\circ} \mathrm{C}(1 \mathrm{~min}), 45^{\circ} \mathrm{C}(1 \mathrm{~min}) \\
72^{\circ} \mathrm{C}(1 \mathrm{~min})-35 \text { cycles }\end{array}$ \\
\hline \multicolumn{3}{|l|}{ HPU2: CTCCTTAATTGTTTTTAC } \\
\hline \multicolumn{3}{|l|}{ Inner primers } \\
\hline AGTTCCTGGTGAGTTGTTCT & 361 & $\begin{array}{l}96^{\circ} \mathrm{C}(30 \mathrm{~s}), 56^{\circ} \mathrm{C}(15 \mathrm{~s}) \\
74^{\circ} \mathrm{C}(30 \mathrm{~s})-40 \text { cycles }\end{array}$ \\
\hline AGCGCCATGAAAACCACGCT & & \\
\hline
\end{tabular}

cations. As a control, we routinely include water in each DNA extraction set. The 16S rDNA gene was amplified by nested PCR using one outer (B37 and C70, a product of about $1500 \mathrm{bp}$ ) and one inner (C97 and C98, about $400 \mathrm{bp}$ ) primer pair for the Helicobacter genus (Table I). Another nested PCR for H. pylori ureA ( 311 bp) was also used as previously described (Wang et al. 1993) (Table I). An Escherichia coli strain (clinical isolate) and an $H$. pylori strain (TX30A) served as negative and positive controls, respectively, and distilled water was used as an internal reaction negative control. PCR targeting the beta-globulin gene was used for testing residual inhibitors as previously described (Verhoef et al. 2003).

The nested 16S rDNA PCR products of $400 \mathrm{bp}$ were purified (Wizard PCR-Prep purification kit, Promega, Madison, WI, USA) and directly sequenced in an Applied Biosystems DNA automated sequencer (ABI PRISM 310, Applied Biosystems, Foster City, CA, USA), using and ABI PRISM BigDye Terminator Cycle Sequencing Ready Reaction Kit and sequencing primers C97 and C98. The sequences were aligned using the cap program at the INFOBIOGEN web server and compared with the GenBank database with the BLAST program on the National Center for Biotechnology Information computer server. The 16S rDNA gene sequences were deposited in GenBank (accession HM246653-HM246661). We also evaluated the presence of the signal sequence of vacA, a specific $H$. pylori gene present in all the strains, by one step PCR (Atherton et al. 1995).

\section{RESULTS}

The nested PCR for the 16S rRNA gene was positive in 24 of the 30 gastric biopsies $(80 \%)$. The results were confirmed by the ureA nested PCR. In six cases, neither the nested PCRs nor the vacA PCR were positive. In the 24 H. pylori-positive gastric mucosa samples, vacA was detected by one step PCR in 22 samples (91.7\%), the s1 genotype was observed in $18(81.8 \%)$, s2 in two (9.1\%) and both s1 and s2 in two (9.1\%) cases. Although vacA was not directly detected by PCR in two samples, the 400 bp product obtained from the 16S rRNA gene nested PCR in these samples was observed to be $99 \%$ similar to H. pylori by sequencing.

The nested PCR for the 16S rRNA gene was positive in nine (30\%) and six (20\%) samples of saliva and dental plaque, respectively. The vacA gene was observed in two saliva (1 s1 and $1 \mathrm{~s} 2$ genotype) and two dental plaque (2 s1 genotypes) samples; the nested 16S rRNA gene was positive in all of them. The vacA genotypes were identical to those observed in the corresponding gastric mucosa. The PCR for vacA was positive in a significantly higher percentage of gastric mucosa samples than the oral cavity samples $(\mathrm{p}<0.0002$, Chi-square test with Yates correction). The results are summarised in Table II. 


\section{TABLE II}

Detection of Helicobacter pylori genes in the gastric and oral cavity samples of 30 patients by one step and nested polymerase chain reaction (PCR)

\begin{tabular}{lccc}
\hline Site & $\begin{array}{c}\text { VacA } \\
\text { PCR } \\
\mathrm{n}(\%)\end{array}$ & $\begin{array}{c}\text { 16S rDNA } \\
\text { nested-PCR } \\
\mathrm{n}(\%)\end{array}$ & $\begin{array}{c}\text { 16S rDNA } \\
\text { sequencing }^{a} \\
\mathrm{n}(\%)\end{array}$ \\
\hline Gastric mucosa & $22(73.3)$ & $24(80)$ & $10(100)^{b}$ \\
Saliva & $2(6.7)$ & $9(30)$ & $7(77.8)$ \\
Dental plaque & $2(6.7)$ & $6(20)$ & $4(66.7)$ \\
\hline
\end{tabular}

a: $>99 \%$ similarity with H. pylori; $b: 10$ PCR products from the gastric mucosa were sequenced.

All 400 bp products obtained from the saliva and dental plaque and 10 obtained from the stomach were sequenced. In seven positive PCR from saliva, four from dental plaque and all from the gastric mucosa, the sequencing showed $>99 \%$ identity with $H$. pylori. For all of the positive oral cavity samples, positive results were also observed in the corresponding gastric mucosa sample. In addition, the sequencing of the $400 \mathrm{bp}$ products obtained from two samples of saliva and two samples of dental plaque showed other microorganisms that are closely related to the Helicobacter genus phylogenetically: Campylobacter concisus ATCC 33237 (96\% similarity) and candidatus Wolinella africans AS-7 (97.3\% similarity) in the saliva samples and Campylobacter rectus LMG 7611 (95.8\% similarity) and Campylobacter sp. oral clone BB.120 (91\% similarity) in the dental plaque samples. Therefore, the presence of specific $H$. pylori DNA was truly detected in only $23.3 \%$ of the saliva samples and $13.3 \%$ of the dental plaque samples. Considering that in two patients the DNA was detected simultaneously in the saliva and dental plaque, the overall detection rate was $30 \%$.

\section{DISCUSSION}

In this study, we evaluated the presence of $H$. $p y$ lori genes in specimens from the oral cavity (saliva and dental plaque) and gastric mucosa of dyspeptic patients. As shown in Table III, the percentage of saliva or dental plaque $H$. pylori DNA-positive samples we observed was in line with that demonstrated by Parsonnet et al. (1999) and Mapstone et al. (1993), whose study designs, similarly to ours, included PCR amplicon sequencing or control for the presence of the most closely related non-Helicobacter spp or other Helicobacter. By contrast, the overall detection rate of $H$. pylori in our study was higher than that reported by Hardo et al. (1995) in a low H. pylori prevalence area and by Fritscher et al. (2004) who evaluated children. Conversely, in the studies of Song et al. (2000) and Loster et al. (2006) the frequency of $H$. pylori in the oral cavity was higher than that of the present study. However, non-specific methods were used for bacterium identification in these studies. The discordance among the studies may be explained by differences in either the prevalence of gastric $H$. pylori infection or in the accuracy of the methods used. The age of the patients may also be important because the prevalence of infection increases with increasing age. In the present paper, we employed a highly-sensitive nested PCR. This assertion is supported by the results we observed in the gastric mucosa with respect to the prevalence of $H$. pylori infections that were similar to that observed from previous studies in the same geographic region and employing several diagnosis methods such as culture, preformed urease test, stained smears and serology (Queiroz et al. 1999). In addition, saliva and dental plaque samples were truly positive for $H$. pylori by the nested PCR in seven and four specimens, respectively, and by vacA one step PCR in only two specimens from each site. This PCR has successfully been used in studies evaluating the presence of $H$. pylori in non-gastric sites by our group (Silva et al. 2003, Oliveira et al. 2004) and others (Fox et al. 1998). Conversely, although the method was highly specific for the diagnosis of $H$. py-

TABLE III

Positivity for Helicobacter pylori in the oral cavity by polymerase chain reaction methods

\begin{tabular}{|c|c|c|c|c|}
\hline Reference & Sample & $\begin{array}{c}\text { Patients } \\
\mathrm{n}\end{array}$ & $\begin{array}{l}\text { Gastric } \\
\text { H. pylori } \\
\mathrm{n}\end{array}$ & $\begin{array}{c}\text { Oral cavity } \\
\text { H. pylori positivity } \\
\mathrm{n}(\%)\end{array}$ \\
\hline Parsonnet et al. (1999) & Saliva & 26 & 16 & $7(43.8)$ \\
\hline Mapstone et al. (1993) & Dental plaque/saliva & 23 & 13 & $5(38.5)$ \\
\hline Hardo et al. (1995) & Dental plaque & 62 & 34 & $1(2.9)$ \\
\hline Song et al. (2000) & Dental plaque & 21 & 10 & $10(100)$ \\
\hline Fritscher et al. (2004) & Dental plaque/oral mucosa & 105 & ND & $9(8.6)$ \\
\hline Loster et al. (2006) & Oral mucosa & 40 & 40 & $40(100)$ \\
\hline Olivier et al. (2006) & Dental plaque & 79 & 66 & 0 \\
\hline Present paper & Dental plaque/saliva & 30 & 24 & $9(30)$ \\
\hline
\end{tabular}

ND: not determined. 
lori infection in the gastric mucosa in this study and in bile or gallbladder and intestinal mucosa in other studies from our group (Silva et al. 2003, Oliveira et al. 2004), the specificity was low in the case of saliva $(77.8 \%)$ and dental plaque (66.7\%). In fact, because the oral cavity is the habitat of many bacterial species very closely related to H. pylori, such as several species of Campylobacter and Wolinella (up to $97 \%$ similarity with $H$. pylori), false positive results for Helicobacter may occur. We overcame this problem by sequencing the PCR products and demonstrating that a significant proportion of positive PCR for H. pylori observed in the oral cavity was, in fact, false-positive results due to the presence of closely related non-Helicobacter species.

Different from the data we obtained in the gastric mucosa by single-step PCR, most of the Helicobacter DNA was only detected in the oral cavity by nested PCR, indicating that the number of bacteria is smaller at this site than in the gastric mucosa. In addition, there was no positive result with the saliva or plaque specimens from the patients who tested negative in their gastric mucosa specimens and the bacterium vacA genotypes observed in the mouth were seen to be the same as those observed in the stomach. These results suggest that $H$. pylori may be transient in the oral cavity, probably due to either pathologic or physiologic gastroesophageal reflux. The lower detection rate of the vacA gene in the saliva and dental plaque samples is probably due to a low bacterial load found in the oral cavity as mentioned above.

Our results suggest that $H$. pylori does not establish persistent oral colonisation and, thus, is very unlikely to play a role in oral diseases. Conversely, we may not rule out the possible participation of $H$. pylori present in the oral cavity in the transmission of infection by the oral route. It has to be emphasised that the infection is mainly acquired in childhood and $H$. pylori-positive mothers are an independent risk factor for infection (Rocha et al. 2003). The intimate contact of the mother with her babies and the putative susceptibility of young child to become infected with a small number of the microorganisms may support the hypothesis that $H$. pylori transiently localised to the oral cavity may have a relevant role in the transmission of infection.

In conclusion, H. pylori may transiently be found in the oral cavity of patients with gastric infection and it may be a source of the bacterium for the transmission of infection by the oral route. Furthermore, methods based only on PCR for the detection of $H$. pylori at oral sites should be interpreted with caution due to the presence of other microorganisms in the mouth that are phylogenetically related to $H$. pylori.

\section{REFERENCES}

Atherton JC, Cao P, Peek RM Jr, Tummuru MK, Blaser MJ, Cover TL 1995. Mosaicism in vacuolating cytotoxin alleles of Helicobacter pylori. Association of specific vacA types with cytotoxin production and peptic ulceration. J Biol Chem 270: 17771-17777.

Fox JG, Dewhirst FE, Shen Z, Feng Y, Taylor NS, Paster BJ, Ericson RL, Lau CN, Correa P, Araya JC, Roa I 1998. Hepatic Helico- bacter species identified in bile and gallbladder tissue from Chileans with chronic cholecystitis. Gastroenterology 114: 755-763.

Fritscher AM, Cherubini K, Chies J, Dias AC 2004. Association between Helicobacter pylori and recurrent aphthous stomatitis in children and adolescents. J Oral Pathol Med 33: 129-132.

Hardo PG, Tugnait A, Hassan F, Lynch DA, West AP, Mapstone NP, Quirke P, Chalmers DM, Kowolik MJ, Axon AT 1995. Helicobacter pylori infection and dental care. Gut 37: 44-46.

Loster BW, Majewski SW, Cześnikiewicz-Guzik M, Bielanski W, Pierzchalski P, Konturek SJ 2006. The relationship between the presence of Helicobacter pylori in the oral cavity and gastric in the stomach. J Physiol Pharmacol 57 (Suppl. 3): 91-100.

Mapstone NP, Lynch DA, Lewis FA, Axon AT, Tompkins DS, Dixon MF, Quirke P 1993. Identification of Helicobacter pylori DNA in the mouths and stomachs of patients with gastritis using PCR. J Clin Pathol 46: 540-543.

Mégraud F, Lamouliatte H 1992. Helicobacter pylori and duodenal ulcer. Evidence suggesting causation. Dig Dis Sci 37: 769-772.

Oliveira AG, das Graças Pimenta Sanna M, Rocha GA, Rocha AM, Santos A, Dani R, Marinho FP, Moreira LS, de Lourdes Abreu Ferrari M, Moura SB, Castro LP, Queiroz DM 2004. Helicobacter species in the intestinal mucosa of patients with ulcerative colitis. J Clin Microbiol 42: 384-386.

Olivier BJ, Bond RP, van Zyl WB, Delport M, Slavik T, Ziady C, Terhaar Sive Droste JS, Lastovica A, van der Merwe SW 2006. Absence of Helicobacter pylori within the oral cavities of members of a healthy South African community. J Clin Microbiol 44: 635-636.

Parsonnet J, Friedman GD, Vandersteen DP, Chang Y, Vogelman JH, Orentreich N, Sibley RK 1991. Helicobacter pylori infection and the risk of gastric carcinoma. N Engl J Med 325: 1127-1131.

Parsonnet J, Shmuely H, Haggerty T 1999. Fecal and oral shedding of Helicobacter pylori from healthy infected adults. JAMA 282: 2240-2245.

Queiroz DM, Mendes EN, Rocha GA, Oliveira AM, Oliveira CA, Cabral MM, Nogueira AM, Souza AF 1999. Serological and direct diagnosis of Helicobacter pylori in gastric carcinoma: a case-control study. J Med Microbiol 48: 501-506.

Rocha GA, Rocha AMC, Silva LD, Santos A, Bocewicz AC, Queiroz Rd R de M, Bethony J, Gazzinelli A, Corrêa-Oliveira R, Queiroz DM 2003. Transmission of Helicobacter pylori infection in families of preschool-aged children from Minas Gerais, Brazil. Trop Med Int Health 8: 987-991.

Silva CP, Pereira-Lima JC, Oliveira AG, Guerra JB, Marques DL, Sarmanho L, Cabral MM, Queiroz DM 2003. Association of the presence of Helicobacter in glallbladder tissue with cholelithiasis and cholecystitis. J Clin Microbiol 41: 5615-5618.

Song Q, Haller B, Ulrich D, Wichelhaus A, Adler G, Bode G 2000. Quantitation of Helicobacter pylori in dental plaque samples by competitive polymerase chain reaction. J Clin Pathol 53: 218-222.

Verhoef C, Pot RG, de Man RA, Zondervan PE, Kuipers EJ, IJzermans JN, Kusters JG 2003. Detection of identical Helicobacter DNA in the stomach and in the non-cirrhotic liver of patients with hepatocellular carcinoma. Eur J Gastroenterol Hepatol 15: 1171-1174.

Wang JT, Lin JT, Sheu JC, Yang JC, Chen DS, Wang TH 1993. Detection of Helicobacter pylori in gastric biopsy tissue by polymerase chain reaction. Eur J Clin Microbiol Infect Dis 12: 367-371.

Wotherspoon AC, Ortiz-Hidalgo C, Falzon MR, Isaacson PG 1991. Helicobacter pylori-associated gastritis and primary B-cell gastric lymphoma. Lancet 338: 1175-1176. 